\title{
A teoria do romance e a análise estético- cultural de M. Bakhtin
}

\author{
Irene A. Machado
}

\section{Poética histórica: metalinguagem e fronteiras da análise estética}

Năo resta dúvida de que a obra do teరrico russo Mikhail Bakhtin (1895-1975) tem sido alvo de leituras um tanto equivocadas em nosso meio intelectual. Quando suas reflexठes cobre a poeticidade do discurso literário năo săo confundidas com os princípios da análise do discurso, desenvolvidos pela lingülstica, as categorias básicas de seu método crftico - por exemplo, a carnavalização e o dialogismo - săo submetidas a simplificaçōes e generalizaçōes assustadoras.

Embora Bakhtin tenha colocado no centro de suas preocupaçōes a intrincada relaçăo que o homem mantém com o mundo atravês da linguagem, năo se pode confinar suas formulaçōes aos limites da lingüfstica, mesmo reconhecendo suas valiosas contribuiçōes nesta área. O conjunto de seus estudos - que Bakhtin reúne sob o nome de Poética histórica - sustenta o firme propósito de compreender a literatura como um fenômeno estético totalmente articulado ao contexto cultural mais amplo. Esta preocupaçăo, que conduziu a análise crfica de obras especfficas - como a de Dostoiévski e Rabelais - no sentido de apreender sua poética, foi também objeto de estudos téricos desenvolvidos ao longo de vários anos. Săo exatamente esses ensaios, reunidos ulteriormente (1975) no volume Questóes de literatura e de estética: a teoria do romance, que nos interessa examinar neste momento, quando podernos contar com a versăo em portugues, realizada a partir do original russo e publicada em 1988 e cuja qualidade e nivel devem ser ressaltados.

Se no fivro sobre Dostoiévski o alvo de Bakhtin era uma questão especffica da linguagem literária - a constituiçăo do romance polifơnico à luz da dialogia interna do discurso romanesco no livro sobre Rabelais exercita um outro enfoque. Preocupa-o, agora, apontar a historicidade dos tenómenos da linguagem apreendidos pelo viês da cultura năo-oficial, a chamada cultura popular. As teses esboçadas nestes dois livros, inseridas no conjunto de uma reflexăo teorica mais sistematizada, nos oferecem uma visăo precisa da Pótica histórica elaborada por Bakhtin a partir de suas analises do romance enquanto gênero. Uma leitura atenta destes ensaios de Questóes de literatura e de estética: a teoria do romance certamente revelará a diversidade do pensamento teßrico de Bakhtin e de sua concepçăo de literatura enquanto unidade cultural.

Já no primeiro ensaio, "O problema do conteúdo, do material e da forma na criaçăo literária" (escrito em 1924), Bakhtin afirma a necessidade de analisar os fenômenos literários em sua relaçăo com os demais fenómenos da cultura, apontando para a voga dos estudos lingülsticos que invadiam a critica literária da época. Manifesta, tambêm, sua insatisfação com o enfoque lingǘstico dos problemas da linguagem literária. Propōe uma abordagem que, ultrapassando o domínio lingülstico, alcance o campo da reflexâo estética inserida no contexto geral da cultura, donde o caráter metalingülstico e histórico de sua Poética.

Ao declarar a impossibilidade de examinar os problemas fundamentais da Pótica independente das proposiçōes de uma Estética geral filosófica, Bakhtin tem um interlocutor definido: o formalismo russo e a abordagem lingũlstica que ele pressupőe. Vale a pena anotar que, neste ensaio, năo săo sỏ as criticas ao formalismo que devem ser observadas. Mesmo sem estar teorizando sobre o dialogismo, o método dialogico encontra-se plenamente realizado enquanto proce-

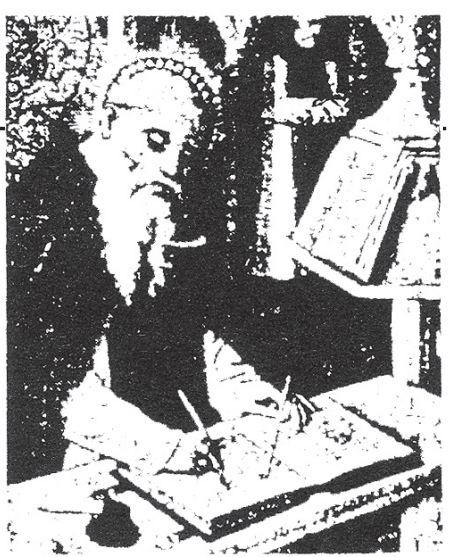

IRENE MACHADO \& protessora da PUC.SP e autora de Analogia do dissimitar (Editora Perspectiva) 
dimento crfico. Bakhtin penetra no horizonte das formulaçōes que preterde avaliar - o problema do material, do conteúdo e da forma - a ponto de elaborar enunciados típicos de tal tendência. Ou seja, Bakhtin assume o discurso do outro, esmiuça-lhe os aspectos mais obscuros e, somente após este convfvio com o universo das idéias do adversário, è que lança seus questionamentos e expōe suas posiçōes. É este procedimento crfico que o leva a condenar a valorizaçăo formalista do material verbal ditado pela lingülstica, com o objetivo preciso de mostrar a impossibilidade de ignorar que todo ato cultural (conhecimento, ética, arte) "vive sobre fronteiras, vive ultrapassando seus próprios limites" (p. 29), inviabilizando a análise estếtica fora do contexto cultural.

Deste modo, Bakhtin elege o conteódo da atividade estética, e nẫo o material, como o objeto primordial de análise. Embora a discussăo sobre forma/conteúdo já tenha sido superada, năo podemos deixar de mostrar como Bakhtin enfrentou o problema na perspectiva de seu método dial $\sigma$ gico. Ele entende o conteúdo como o elemento ético-cognitivo que evidencia a relaçăo entre a açăo humana $e$ o mundo onde esta se desenvolve. É o conhecimento que revela a capacidade potencial de os seres vivos reagirem ao meio em que vivem. Esta reação tornou-se o centro das reflexōes de Bakhtin sobre a resposta. Sem resposta năo hâ vida, nem evoluçăo e nem tampouco se pode definir o tipo de relaçăo que o homem mantém com o mundo. Antes mesmo de o dialogismo ganhar a dimensăo de unidade para a análise cultural e se transformar no conceito-chave de sua Poética, Bakhtin se dedicara ao estudo da resposta na relaçăo dialógica do homem com o mundo. Suas reflexðes neste sentido constam do ensaio "Arte e responsabilidade" de 1919. Foi pensando nesta açăo responsiva que se irradia pelos vários nlveis da vida biológica, social e cultural que Bakhtin afirma a impossibilidade da análise estética imanente. Ao contrário do que se pretende, "a arte celebra, orna, evoca essa realidade preexistente do conhecimento e do ato"( $p$. 33). É isto que faz da novidade o elemento vital da atividade estética. Para Bakhtin, arte é resposta, uma vez que ela cria uma nova relaçăo axiolßgica com aquilo que já se tornou realidade para o conhecimento e para o ato. Estes sim săo primordiais e năo podem ser ignorados pela análise estética.

Tendo em vista o caráter inaugural do conhecimento e do ato, Bakhtin reconsidera a questăo do material e da forma, elementos privilegiados pela análise lingǘstica. A forma parece-lhe antes um atributo do conteúdo, pois somente a forma esteticamente significante é expressăo de uma relaçăo substancial com o mundo do conhecimento e do ato. O objeto estético năo é uma coisa; é um conteúdo dotado de forma "na qual eu me sinto como um sujeito ativo" (p. 69). Esta é a propriedade estética da forma. Daf́ a defesa do "método de análise estética da forma enquanto forma arquitetonica" (p. 57), vale dizer, aquela que organiza os valores cognitivos e éticos. Para Bakhtin, quem năo consegue perceber a dimensăo arquitetônica da forma e sua atividade significante reduz os estudos poéticos à análise do material lingülstico, em poesia, e do enredo no romance.

A palavra é, nessa perspectiva, o limite da cultura (p. 45). Entretanto, cada ato cultural usa a palavra de modo diferente. O conhecimento năo tem o que fazer, por exemplo, com o aspecto sonoro da palavra. Embora a cultura seja um fenômeno de lingua e năo viva sem ela, o dominio cultural tira dela muito pouco. Nesse sentido, a poesia revela sua particularidade em relaçăo aos outros atos culturais: somente a poesia precisa da lingua por inteiro, valorizando os mínimos aspectos de sua constituiçăo material. "É como se a poesia espremesse todos os sucos da lingua que aqui se supera a si mesma"(p. 48).

Só aparentemente este primeiro ensaio parece desvinculado da temática dos demais, voltados para a poética do romance. No entanto, é aqui que Bakhtin fixa as diretrizes de uma poética em que o fato estético é entendido inclusive pelos seus aspectos culturais.

\section{Uma poética do discurso}

A análise do objeto estético, no conjunto da cultura humana, é a resposta que a Poética histórica bakhtiniana apresenta aos estudos literários de sua época, no sentido de eliminar as dicotomias tăo arraigadas aos princlpios de análise. Quando Bakhtin afirma a importância decisiva da palavra na definiçăo da própria cultura, na verdade, ele está conferindo à lingua uma noçăo muito particular, fundamental, contudo, para se compreender muitas de suas concepçøes. Para Bakhtin, a lingua é basicamente a manifestaçăo de uma visăo de mundo e tem uma realizaçăo efetiva no discurso. Eis o elemento primordial de sua análise estético-literária. O discurso é uma enunciaçăo que torna possfvel considerar a performance da voz que o enuncia e o contexto social em que $e ́$ enunciado. Entende, deste modo, a impossibilidade de analisar o discurso fora do ambiente em que ê realizado e que atribui à palavra seu matiz ideologico, vale dizer, dialogico. Para 
Bakhtin năo existe palavra lingūisticamente virgem, năo atingida pelo contexto. "Somente Adăo mfico desbravou, com seu primeiro discurso, um mundo ainda verbalmente năo-dito e pôde evitar totalmente a relaçăo dialógica com vistas ao discurso do outro. Isto jamais ocorreu com o discurso concreto e histórico, que năo pode se estruturar de um único modo nem se dirigir a um único ponto" (p. 102). Esta é uma resposta notável a toda tendência que năo considera o discurso como um ato social em que o Eu relaciona-se com o Outro atravês da linguagerr. Săo estas concepçōes tăo inovadoras que levam Bakhtin a elaborar um dos ensaios mais fecundos desta coletânea. Trata-se do estudo "O discurso no romance" (escrito entre 1934-1935), que merece, de nossa parte, um exame detalhado.

Considerando que o processo de interaçăo die ßogica, desenvolvido nas diversas esferas da atividade humana, gera infinitas modalidades comunicativas, săo igualmente infinitas as espécies de gêneros discursivos, que Bakhtin reuniu. Dentre esta variedade de gêneros discursivos, destacam-se os gêneros do discurso literário, mais especificamente a prosa romanesca. É nesta modalidade de discurso que Eakhtin vai encontrar elementos concretos para a explicitaçăo da forma significante, a que aludira no ensaio anterior, pois acreditava que nos gêneros do discurso literário se acumulam, durante séculos, formas de compreensão de determinadcs aspectos do mundo, cujos sentidos explicitam o caráter de uma época e seu desdobramento futuro. $E$, segundo Bakhtin, o único gênero que soube representar toda a dinâmica desse grande tempo foi o romance. Suas reflexōes sobre o romance estăo de tal modo tomadas pela preocı paçăo de desvelar, na forma enunciativa, o dimensioramento ideologico, que se tornaram um verdadeiro manifesto sobre a cultura de nossa era. Bakhtin empreende uma leitura entusiástica e apaixonac' 't do romance pois entŁnde ser ele, năo sơ a sintese das representaçŏes culturais formadas ao longo do tempo, como também um embrião de procedimentos para composiçōes futuras. O romance ê um gênercı que, ao debruçar-se sobre o presente, descobre um tempo que năo é o seu. Este diálogo transtemporal estimula o fascínio de Bakhtin e o leva a elaborar uma das mais notáveis teorias do romance, cujos pontos principais se concentram neste ensaio.

A idéia central desta teoria ê a noçăo de romance como um gênero em devir. Além de desestabilizar a clássica teoria dos gêneros poéticos, assentada sobre formaçōes precisas e estruturas canônicas, esta concepção de Bakhtin polemiza com algumas tendências atuais que entendem o romance como um gênero que viveu a plenitude de suas formas no século XIX, encontrando-se definitivamente morto neste século. Bakhtin năo compactua com esta tendência e considera o inacabamento da estrutura composicional do romance o traço maior de sua poeticidade. Dal a inoperância da estilistica tradicional na apreensăo deste tipo de formaçăo poética. $\mathrm{O}$ estilo do romance é antes uma combinaçăo de estilos agenciados, sobretudo, pela diversidade social de linguagens que organizam artisticamente sua composiçăo, dificultando, assim, a consolidaçăo de uma estrutura canônica, premissa elementar dos gêneros poéticos. Aliass, a verdadeira premissa da prosa romanesca é, para Bakhtin, a estratificaçăo interna da linguagem, que torna o romance um fenômeno pluriestillstico, plurillngũe e plurivocal. É por estas vias que Bakhtin envereda no sentido de apreender os nfveis de poeticidade da palavra no romance.

Bakhtin reconhece que o romance trouxe um dilema para a estillstica e filosofia do discurso, colocadas, assim, ante um impasse: ou reconheciam o romance e a prosa literária que gravita em torno dele como gêneros nåo-literários, ou seriam obrigadas a rever de maneira radical a concepçăo de discurso poético. Bakhtin parte exatamente de uma revisăo da noçăo de gênero, pois entende que a poeticidade do discurso líterário, depois do surgimento do romance, năo podia ser pensada fora do contexto da dialogia interna da linguagem. A dialogia supera o símbolo poético do tropo e torna-se, conseqũentemente, o traço distintivo deste discurso a que Bakhtin chama prosa poética. Um discurso moldado pelo arranjo de vozes através das quais ressoa a voz do poeta prosador. O discurso poético assim concebido năo é mais emanação de um Eu lírico individual e soberano, que oculta a vida plena de dialogia em que o poeta vive.

É importante ressaltar que ao eleger o romance como um discurso poético privilegiado, Bakhtin não depōe contra a poesia (poema), nem a nega enquanto discurso, como pode parecer à primeira vista. O problema é que Bakhtin opera com um aspecto năo-previsto pela clássica teoria dos gêneros poéticos. Tomar a dialogia da prosa como um traço distintivo do discurso poético significa reverter totalmente as regras do gênero. Para Bakhtin, o poema que exclui a interaçăo entre discursos e em que o poeta não acede ao pensamento de outrem năo é poesia. Poesia é manifestaçăo de uma consciência poética que vê, imagina e compreende o mundo, năo com os olhos de sua linguagem individual, mas com os olhos de outrem. Por isso, a linguagem dos gêneros poéticos canonizados é, para Bakhtin, autoritária, dogmática, conservadora.

Tudo isso levou Bakhtin a considerar a poesia como um discurso monológico, a temer a linguagem única da poesia e a condenar com veemência o conceito de linguagem poética defendido 
pelos poetas simbolistas (Balmont, Ivanov), pelos futuristas (V. Khliebnikov) e tornado a chave do formalismo russo. Devemos esclarecer, contudo, que - pelo menos no que se refere a Khliébnikov - o temor de Bakhtin năo procede, visto que a poesia zaúm assumiu a poeticidade articulada na (in)tensa vivência da palavra no contexto dinâmico da lingua e num universo pluralista de linguagens. Embora este exercicio de linguagem tenha escapado a Bakhtin, ele năo deixou de perceber a riqueza dialógica do discurso poético de Horácio, Villon, Heine, Laforgue, Ânienski e de Púchkin, de quem analisa alguns fragmentos do notável Evguiênin Oniêguin. Estas poucas páginas, que ocupam dois capfulos do ensaio sobre o discurso no romance (pp. 85-133), merecem uma leitura particular daqueles que desejam entender o conceito de poesia que Bakhtin tinha em mente ao se propor estudar a poética da prosa romanesca.

Avançando sua análise sobre a poeticidade da palavra no romance, Bakhtin afirma que a Ilngua, enquanto meio vivo e concreto onde vive a consciência do artista da palavra, năo é única. Cada palavra evoca um ou vários contextos nos quais ela viveu sua vida socialmente tensa, o que sugere a Bakhtin a intencionalidade das palavras e formas. Esta densidade intencional torna o discurso poético uma manifestaçăo plurilinguñe: trata-se năo de uma linguagem, mas de um diâlogo de linguagens. A tarefa do poeta prosador é tornar este discurso, já povoado pelas intençōes sociais de outrem, o elemento primordial de seu fazer, obrigando-o, evidentemente, a servir a suas novas intençōes. Este procedimento enfatiza o aspecto elementar do plurilingüismo no romance: a bivocalidade do discurso direto do autor, que serve sempre a dois locutores e a duas intençбes.

Deste modo, o campo de representação da voz (do autor ou do personagem) é muito mais amplo do que seu discurso direto. Através dele correm outros gêneros discursivos igualmente definidores do caráter da prosa romanesca. Trata-se das formas que aproximam o romance dos gêneros retóricos, que sempre dificultaram a definição do romance enquanto gênero poético. Para Bakhtin, entretanto, os gêneros retóricos - que ele chama de gêneros intercalados - săo uma fonte inesgotável do plurilingüismo do romance, pois săo eles que trazem para o romance uma diversidade de linguagens. "Em princípio - afirma Bakhtin - qualquer gênero pode ser introduzido na estrutura do romance e, de fato, é muito diffcil encontrar um gênero que náo tenha sido alguma vez inclufdo num romance por algum autor" (p. 124). Há inclusive aquele grupo especial de gêneros que exercem um papel decisivo na estrutura romanesca a ponto de determinar-lhe o perfil composicional. É o caso da confissăo, do diário, das cartas, das biografias. "Todos esses gêneros que entram para o romance - acrescenta Bakhtin - introduzem nele suas linguagens e, portanto, estratificam sua unidade lingülstica e aprofundam de um novo modo seu plurilingüismo" (p. 125). Querer entender o romance fora dessa dialogia interna é reduzir a linguagem romanesca a meras indicaçōes cênicas, perspectiva totalmente avessa ao problema central da prosa poética, vale repetir, o discurso bivocal internamente dialogizado.

O plurilingüismo entra no romance "em carne e osso" nas vozes das pessoas que falam. A lingua no romance năo só representa, mas ela própria é objeto de representaçăo. A dialética da representaçăo se configura pelo dimensionamento ideológico da palavra no romance: a palavra de um homem que fala em nome de uma visão de mundo ou de um sistema de idéias. A propósito lembra Bakhtin que o diálogo socrático é o primeiro documento que reflete o nascimento simultâneo do conceito cientfico $e$ da nova personagem romanesca na arte literária em prosa: a figura central do gênero é uma pessoa que fala e que conversa. O sujeito que fala no romance é sempre um ideólogo e sua palavra é sempre um ideologema: representa um ponto de vista particular sobre o mundo (p. 135). Entretanto, o romance năo opera com a imagem do homem, mas com a imagem de sua linguagem, o que equivale dizer que a palavra do homern que fala năo é apenas transmitida em seus constituintes verbais, mas é representaçăo literária pelo discurso do autor. A palavra no romance é sempre palavra citada, representada; é discurso de outrem. Este é outro conceito fundamental da poética do discurso romanesco elaborada por Bakhtin. Por isso, estudar as formas de transmissão dessa palavra parece-lhe uma tarefa indispensável para compreender a dialética do plurilingûismo das enunciaçōes. É aqui que a bivocalidade se revela em toda a sua plenitude. $\dot{E}$ aqui também que Bakhtin situa a derrocada da consciência ptolomaica da linguagem, imposta pelos gêneros elevados, e a progressiva formaçăo de uma consciência galileana, sem a qual o romance năo se sustentaria enquanto gênero muitiforme. Tudo isto está na base do dialogismo literário e da conceptualizaçăo do romance polifônico que, de modo tăo incisivo, tem identificado a Poética histórica de Bakhtin.

Para mostrar o rornance como expressâo da consciência galileana da linguagem, que recusa o absolutismo da lingua única em nome do plurilingüismo das línguas nacionais, Bakhtin contrapóe duas linhas do romance europeu: uma constitulda pela linguagem enobrecida e outra calcada na diversidade e no confronto de linguagens. A primeira iinha do romance europeu nasce com o romance sofista, que elabora uma prosa de exposiçăo onde a linguagem é entendida como um 
elemento neutro e agradável. $\mathrm{E}$ al que se desenvolve a categoria da literaturidade da linguagem (p. 176). Ou seja, o enobrecimento da linguagem marcada pela fluência e suavidade do estilo sem dialogizá-lo nem despertar dissonâncias dialógicas abruptas. O romance de cavalaria é o romance citado por Bakhtin como exemplo desta tendência. Nele se desenvolve uma linguagem falada num clrculo literário cultivado, dal sua pretensăo em fornecer as normas à linguagem corrente, ensinar o bom estilo e o bom-tom da conversaçăo. É um tipo de discurso que se opōe à palavra vulgar com suas opçōes grosseiras. Para Bakhtin, contudo, Cervantes já elabora um discurso em que há o encontro do discurso enobrecido com o discurso vulgar.

É importante esclarecer o contexto real do conceito bakhtiniano de literaturidade, tăo fundamental a este tipo de romance. Numa nota à página 176 da versăo brasileira, o tradutor observa que literaturidade - correspondente ao termo russo literaturnost - já está consagrado em crtíca literária. Gostarfamos de ressaltar, a fim de evitar confusōes, que o conceito de literaturidade ou literariedade que está consagrado é aquele formulado por Roman Jakobson em seu estudo sobre a linguagem poética, e não o de Bakhtin, apresentado neste ensaio. Embora o termo seja o mesmo, o contexto teórico é distinto. Em Jakobson trata-se de valorizar os elementos expressivos responsáveis pela criaçăo da poeticidade da linguagem; em Bakhtin o que está em jogo é o contraponto entre a linguagem culta (enobrecida) e a linguagem vulgar.

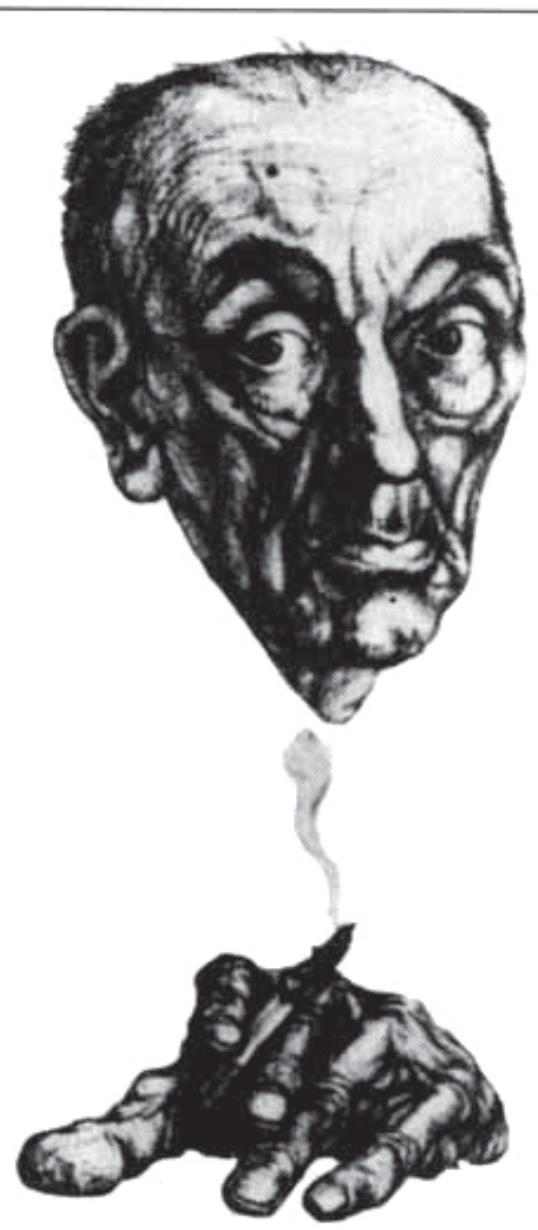

A par deste tipo de romance, elaborado pela categoria da literaturidade, Bakhtin trata do romance barroco, constituído pela concepção do mundo em sua unidade contraditória de tensōes. $O$ romance barroco é também denominado "romance de provaçōes": provação do herói e de sua palavra. Este tipo de romance reúne em sua estrutura interna uma diversidade de gêneros intercalados, provocando o plurilingũismo. O romance abriga, deste modo, a possibilidade de testar seu discurso através do confronto com outros discursos, como entende Bakhtin ser o caso de Sterne. É exatamente este o tipo de romance que engendra o discurso romanesco valorizado por Bakhtin.

Tendo em vista que o problema central da estillstica romanesca ê a representação literária da imagem da linguagem, Bakhtin confere importância a certos procedimentos como a paródia, a estilizaçăo e o skaz. Enquanto o skaz revela a orientaçăo para a fala presente no discurso, a estilização mostra como a prosa aprendeu a representar artisticamente o estilo de outrem. É, todavia, a paródia que Bakhtin discute mais demoradamente neste momento. À luz do fenómeno parठdico, Bakhtin pôde encontrar no romance o traço fundamental do dialogismo, quer dizer, a relaçăo com o outro. O romance é a alteridade dos gêneros constituldos. Nele, vários planos se entrecruzam, ora em harmonia, ora em profunda tensão; mas com um único objetivo: relativizar tudo o que já está definido. Por exemplo: o poema no romance deixa de ser poema, no sentido estrito do termo, e passa a integrar a estrutura da prosa romanesca; o discurso através do qual se manifesta é antes uma paródia da própria poesia. É o que acontece, como lembra Bakhtin, com os sonetos que introduzem o Dom Quixote: năo se trata mais de soneto (gênero), mas da imagem do soneto. Esta propriedade de o discurso parठ́dico transformar-se num outro, ainda que conserve a estrutura do discurso anterior, mantém uma vinculaçăo muito estreita com aquilo que Bakhtin denominou carnavalizaçăo na literatura. O discurso paródico, pleno de inversōes, ironias, ambivalências, reverte para a literatura as formas sincréticas do espetáculo carnavalesco, estudadas com minúcia por Bakhtin em seu livro sobre Rabelais. 
A parठdia liga-se, deste modo, à mais antiga forma de representaçăo da linguagem: o riso que, juntamente com o plurilingüismo, constituem a pré-história do discurso romanesco ( $\mathrm{pp}$. 363-396). A criaçăo paródico-travestizante introduz um corretivo constante de riso e de crftica na seriedade do discurso direto elevado. Afinal, o romance é perspectivado pelos gêneros inferiores e pelas forças centrffugas descentralizadoras da vida verbo-ideológica, conforme Bakhtin faz questăo de enfatizar.

\section{A romancizaçăo, o metacriticismo e o drama da evoluçáo literária}

Quando Bakhtin atribui ao romance a característica de gênero em devir, seu objetivo principal é apresentar uma estrutura poética cujas possibilidades plásticas ainda năo foram totalmente exploradas. Quer dizer, o romance é um gênero novo, constituldo a partir das llinguas vivas e das novas formas de recepção advindas da escrita e do livro. Este dado novo provoca o interesse de Bakhtin pelas relaçóes entre a épica e o romance, com objetivo de delimitar com maior rigor a "metodologia do estudo do romance", preocupaçăo central do ensaio "Epos e romance", escrito em 1941 (pp. 397-428).

Operando contra o pano de fundo da épica, Bakhtin observa que o romance năo ê um gênero entre outros, mas o único que está evoluindo em meio a outros gêneros já consolidados (p. 398). Sua convivência com estes gêneros é, contudo, conflituosa, nâo há harmonia; pelo contrário, o romance serve-se da paródia para denunciar os graus de convencionalidade das composiçōes estáveis, reinterpretá-las e até mesmo eliminá-las. O romance, enfim, pōe em crise o próprio conceito de gênero como formaçăo estável e se apresenta como antigênero, um metagênero, em desacordo com normas e cânones; reconhece a arbitrariedade e convencionalidade de todas as formas, inclusive de si próprio.

Este olhar corrosivo e ao mesmo tempo criativo, que o romance dirige aos outros gêneros, prefigura a performance do romance na História literária. O romance, quando surge, romanciza os outros gêneros. Romancizar năo significa, contudo, subjugar para mais facilmente impor um cânone estranho aos dominados, pois o próprio romance está privado deste cânone. Trata-se de liberálos (os gêneros subjugados) de tudo o que é convencional, necrosado, empolado e amorto, impedindo sua evoluçăo (p. 427). O fenơmeno da romancização, apontado por Bakhtin, năo é apenas uma implicaçăo direta do caráter parbdico que reina na estrutura interna do romance; é sintoma das alteraçōes e, conseqũentemente, da reordenaçăo dos fenômenos literários dentro de um novo quadro num determinado momento do processo evolutivo. Ou seja, quando o romance se estabelece como gênero predominante, toda a literatura é afetada por uma espécie de criticismo de gêneros. Esta revisăo de posiçōes ante um novo quadro é que permite a reformulaçăo dos constituintes dos gêneros poéticos. Segundo Bakhtin, exatamente por adotar o autocriticismo como um aspecto fundamental de sua estrutura arquitetônica, o romance pôde introduzir a si próprio como objeto de representaçăo. Bakhtin cita, a propósito, o bovarismo que, ao colocar a vida em correlação direta com a leitura de romance, possibilita ao poeta prosador imprimir uma visão crfica nāo sơ aos eventos narrados, mas, sobretudo, aos procedimentos de que se vale a representaçăo.

Ao se revelar como formaçăo inacabada, em permanente evoluçăo, o romance se transforma, aos olhos de Bakhtin, na mais profunda, substancial e sensivel representação da evoluçăo da própria realidade, já que, segundo the parece, "somente o que evolui pode compreender a evolução" (p. 400). Dal a influência decisiva do romance na releitura do processo evolutivo da própria literatura. "O romance tornou-se o principal personagem do drama da evoluçăo literâria na era moderna precisamente porque, melhor do que todos, é ele que expressa as tendências evolutivas do novo mundo; ele é, por isso, o único gênero nascido naquele mundo e em tudo semelhante a ele" (p. 400). Na verdade, todas estas propriedades do romance estudadas por Bakhtin ainda năo tiveram, a meu ver, a devida acolhida nos estudos literários, que năo contam com um instrumental teórico para tratar de formaçōes inacabadas e em evoluçăo. Assentada nos pressupostos da poética do passado (Aristóteles, Horácio, Boileau), a teoria convencional só se aplica às formaçōes consolidadas e em harmonia na unidade temporal.

Colocando o romance na perspectiva da épica, Bakhtin procura valorizar aqueles aspectos que ficam fora de qualquer comparaçăo. Por exemplo, enquanto a épica - a mais sublime expressão dos gêneros elevados - só se dignificou ao representar o passado épico único, distante e glorioso, o romance se alimenta do presente vulgar, instável, transitório. $E$ isso que o situa na perspectiva direta dos gêneros inferiores, as sátiras populares, que fizeram da instabilidade do presente e do sujeito que nele vive o objeto de sua representaçẫo. $O$ gênero sério-cômico torna-se, para Bakhtin, a primeira etapa da evoluçăo do romance enquanto gênero em devir, em prejulzo, inclusive, da épica. É nas representaçōes burlescas que a atualidade entra pela primeira vez co- 
mo objeto de representaçăo literária. "Quando o presente se torna o centro da orientaçăo humana no tempo e no mundo", estes "perdem seu caráter acabado". "O tempo e o mundo tornam-se históricos" (p. 419). O tema do herói que tudo vence perde, assim, terreno no romance, cujos temas gravitam em torno da inadequaçăo do homem ao seu destino; o personagem, ao invês de glorioso e invenclvel, é um ideb́logo em potencial, como já foi referido anteriormente. E o que é mais importante: a épica năo suscita nenhum questionamento, ao passo que o romance, travestido de Sherazade, "especula sobre categorias da ignorância", mantendo aceso o interesse pelo que vem depois. As respostas adiadas săo perguntas em formaçăo, nem sempre resolvidas no final.

\section{A representação dialógica do tempo}

A abordagem bakhtiniana sobre a performance poética do discurso no romance năo se restringe aos problemas de sua estrutura interna, como pode parecer á primeira vista. Quanto mais Bakhtin adentra o universo da representaçăo da palavra, mais ele se aproxima dos problernas formais significantes, das configuraçōes arquitetônicas, da prớpria ideologia, jâ que a palavra no romance é sempre ideologema.

Dentro da perspectiva do dialogismo, a palavra no romance es considerada em sua bidimensionalidade; ela é objeto e instrumento de representaçăo. Enquanto objeto, a linguagem representa a si própria, ê um discurso em devir, capaz de viver um grande tempo e de se relacionar com outros discursos. A linguagem enquanto instrumento de representação passa a ser tamberm configuraçăo de um tempo. As artes verbal e literária săo por natureza representaçð̄es no/do tempo. Esta questăo do tempo e sua representaçăo é o próprio motor da Poética histórica bakhtiniana, sendo, portanto, quase natural que Bakhtin dedicasse a esta questão um estudo especffico. Para examinar de modo mais concreto a noçăo de romance como representaçăo do tempo, Bakhtin convoca uma outra categoria, o cronotopo, objeto primordial do longo ensaio "Formas de tempo e de cronotopo no romance (ensaios de poética histórica)", reservado para explorar os vários momentos da Poética histórica, escrito entre 1937-1938 e finalizado em 1973 (pp. 211-362).

A extensăo do ensaio năo se deve, contudo, à densidade teórica, mas principalmente às análises dos romances através dos quais Bakhtin acompanha a inscriçăo do tempo no espaço da representaçăo. Trata-se de uma ampla abordagem, apoiada em alguns pressupostos téricos, que parte do romance grego, se concentra na obra de Rabelais e chega a considerar alguns aspectos cronotópicos do romance do século XX. Vejamos, ainda que resumidamente, os pontos fundamentais da investigação de Bakhtin.

O termo "cronotopo" ê entendido em toda a sua relaçăo com a teoria da relatividade de Einstein, onde foi introduzido para indicar a interdependência entre o tempo e o espaço, e com a biologia. Nos estudos literários, o cronotopo é entendido como uma "categoria conteudístico-formal" para examinar o "processo de assimilaçăo do tempo, do espaço e do individuo histórico real" (p. 211). O cronotopo permite a materializaçăo do tempo no espaço, como se o tempo se tornasse visivel, transformando-se na quarta dimensăo do espaço. Ou, para usar a notável metåfora bakhtiniana, "o tempo se derrama no espaço e flui por ele (formando os caminhos)" (p. 350).

O cronotopo tem um significado especial na caracterizaçăo do gênero, na medida em que a literatura é uma manifestaçăo verbal totalmente articulada pela dimensăo temporal. Particularmente no que se refere ao romance, o cronotopo tem a funçăo de centro organizador dos principais acontecimentos temáticos; é al que os nós do enredo săo atados e desatados.

Embora Bakhtin năo considere a constituiçăo do romance apenas na tradiçăo do romance grego - mas enfatiza a relaçăo do romance com as manifestaçōes da cultura popular - ele parte do romance antigo para delimitar os tipos de representaçăo do tempo elaborados pelos romances da antigüidade. Ressalta o predominio do cronotopo da aventura no primeiro tipo de romance, em que o herói vive as mais variadas aventuras e desloca-se pelos locais os mais excêntricos e diversificados, sem sofrer, contudo, a minima determinaçâo temporal: no final, é o mesmo jovem que partiu entusiasmado. O tempo năo deixa vestígios em sua vida biológica. Tudo al acontece "de repente" e "justamente", e o acaso governa todos os momentos deste tempo infinito de aventuras, quando o que está em jogo é a castidade, a coragem, a fidelidade, o destemor, a honra do herói ou da heroina.

A literatura romana oferece a Bakhtin um outro tipo de cronotopo. Trata-se do romance de aventuras e de costumes representados pelo Satiricon de Petrônio e pelo Asno de ouro de Apuleio. O aspecto cronotópico fundamental deste romance é a idéia da metamorfose, a partir da qual a vida humana passa a ser representada em seus momentos essenciais de ruptura e crise, quando se indaga como um homem se transforma em outro. O tempo aqui, diferente do tempo da aventura, deixa marcas profundas no homem e em sua vida. Por isso, afirma Bakhtin, esse tipo de romance focaliza os momentos decisivos da vida dos personagens. 
O romance antigo conheceu ainda, segundo Bakhtin, um outro tipo de representaçăo cronotópica herdado das biografias, elaborado inicialmente na obra de Platăo. O romance biográfico desenvolveu basicamente o cronotopo do caminho da vida: é o tema do encontro do verdadeiro conhecimento, que se coloca no primeiro plano da realização temática. A praça pública (a ágora) é o espaço privilegiado deste cronotopo, pois é al que surge pela primeira vez a consciência autobiográfica e biográfica do homem, conforme afirma Bakhtin. O homem deste romance năo conhece a privacidade e toda sua existência é vislvel e audlvel, tal como no reino platônico da idéias.

Avançando seus estudos sobre o cronotopo da praça pública, Bakhtin encontra um outro tipo de representaçăo que acaba recebendo uma atenção especial de sua parte, pois permite-lhe traçar um outro rumo para a evoluçăo do romance. Năo se trata mais da plenitude temporal como ocorria no romance antigo, mas da "ligaçăo particular do homem e de todas as suas açōes e peripécias com o mundo espaço-temporal" (p. 282), no sentido de tirar dal todos os elementos que o corrompem, inclusive a visăo do além e a interpretaçăo simbólica, criando, assim, "um mundo espaço-temporal adequado, um cronotopo novo para um homem novo, harmonioso, inteiro e de novas formas para as relaçőes humanas" (p. 283).

Dirfamos que a sintese do cronotopo em Rabelais está na destruiçăo das falsas relaçōes entre os homens e as coisas de um modo geral. Veja-se, por exemplo, a importância e a conseqũente proliferaçăo de episódios envolvendo a comida e a bebida na obra de Rabelais. A constância deste cronotopo é, para Bakhtin, uma forte expressão do criticismo paródico do texto rabelaisiano. Quer dizer, este cronotopo desmascara uma falsa concepçăo de mundo preconizada pela Igreja, um dos alvos de Rabelais. Enquanto a religiăo prega o jejum, a glutonaria e a bebedeira são fartamente praticadas nos conventos. Ao explorar estas cenas "privadas" e trazê-las para a rua, Rabelais depōe contra uma visăo séria do mundo, fazendo valer o ritual da profanaçăo. Dal os festins pantagruélicos exercerem um papel tăo decisivo na caracterizaçăo do cronotopo rabelaisiano. O corpo é o centro fundamental deste tipo de imagem, em que o gênero humano aparece em seu ciclo vital de crescimento, morte e ressurreiçăo em constante evolução. Por isso, Bakhtin situa este cronotopo na base da literatura grotesca, que comanda toda a 6 gica do realismo fantástico e folcḱrico plenamente desenvolvido e praticado por Rabelais.

Além do romance grego e de Rabelais, săo muitos os cronotopos estudados por Bakhtin: o cronotopo do idnio; do trapaceiro, do bufăo e do bobo; do castelo medieval de Walter Scott; das ruas, cidades e ambientes domésticos de Balzac. Afirma que "o princípio de cronotopia da imagem artístico-literária foi descoberto pela primeira vez, com toda clareza, por Lessing no seu Laocoonte". Para ele, "tudo o que é estático-espacial năo deve ser descrito de modo estático, mas deve ser incluldo na série temporal dos acontecimentos representados e da propria narrativa-imagem". Cita, como exemplo, a descrição da beleza de Helena por Homero, que é realizada a partir dos eleitos sobre os troianos. "A beleza ê introduzida numa cadeia de acontecimentos representados e ao mesmo tempo se apresenta năo como objeto de uma descrição estática, mas como o objeto de uma narrativa dinâmica" (p. 356).

$\mathrm{O}$ estudo do cronotopo desenvolvido por Bakhtin acaba retomando aspectos fundamentais de sua Poética histórica. Os conceitos de paródia, romancizaçăo, e, sobretudo, de discurso romanesco como representaçāo da imagem autêntica da linguagem, comparecem em multos momentos de seu estudo. Bakhtin insiste no caráter "falante, significativo (ou sígnico)" do material que forma a obra: "nós năo o vemos nem tocamos, mas sempre ouvimos a sua voz (mesmo numa leitura silenciosa e de si para si)" (p.357). A voz e o contexto de sua enunciaçăo se colocam como limites para a imagem cronotópica que, por sua vez, é o limite do próprio signo. Afinal, Bakhtin năo deixa de reconhecer que o tempo e o espaço săo categorias imprescindlveis de todo universo imaginário.

\section{BIBLIOGRAFIA}

BAKHTIN, M. A cultura popular na Idade Média e no Renascimento: o contexto de François Rabelais (traduçăo de Yara Frateschi Vieira). Săo Paulo, Hucitec; Brasflia, Ed. da Universidade de Brasfilia, 1987.

-. "Arte y responsabilidad". In Estética de la creación verbal (traduçăo de Tatiana Bubnova). México, Siglo Veintiuno, 1982.

- Problemas da poética de Dostoiévski (traduçăo de Paulo Bezerra). Rio de Janeiro, Forense-Universitária, 1981.

- Questôes de literatura e de estética: a teoria do romance (traduçâo de Aurora F. Bernardini e outros). Săo Paulo, Hucitec e Fund. para o Desenv. da Unesp, 1988. 